\title{
A Pectate Lyase Homolog, xagP, in Xanthomonas axonopodis pv. glycines Is Associated with Hypersensitive Response Induction on Tobacco
}

\author{
S. Kaewnum, S. Prathuangwong, and T. J. Burr
}

First and second authors: Department of Plant Pathology, Faculty of Agriculture, Kasetsart University, Bangkok 10900 Thailand; and third author: Department of Plant Pathology, New York State Agricultural Experiment Station (NYSAES), Cornell University, Geneva, NY 14456.

Accepted for publication 9 June 2006.

\begin{abstract}
Kaewnum, S., Prathuangwong, S., and Burr, T. J. 2006. A pectate lyase homolog, xagP, in Xanthomonas axonopodis pv. glycines is associated with hypersensitive response induction on tobacco. Phytopathology 96:1230-1236.

Xanthomonas axonopodis pv. glycines is the causal agent of bacterial pustule disease of soybeans. A transposon insertional mutant (KU-P$\mathrm{M} 670$ ) of $X$. axonopodis pv. glycines derived from wild-type strain KU-P34017 lost the ability to induce the hypersensitive response (HR) on tobacco and pepper but retained its HR induction capacity on cucumber, sesame, and tomato. The mutation also resulted in loss of ability to cause a potato soft rot and express pectolytic activity at $\mathrm{pH} 6.5$. An approximate
\end{abstract}

ABSTRACT

Bacterial pustule caused by Xanthomonas axonopodis pv. glycines is one of the major bacterial diseases of soybean in Thailand (21). Yield losses of soybean up to $40 \%$ have been reported in certain parts of the world (22). Several plantpathogenic bacteria, including $X$. axonopodis pv. glycines, induce a hypersensitive response (HR) on incompatible or nonhost plants (10). The HR is thought to represent programmed cell death leading to expression of plant defense against disease. It was demonstrated that $X$. axonopodis pv. glycines strain 8ra causes bacterial pustule disease on susceptible soybean cultivars and the HR on pepper and tomato $(11,20)$. Kim and co-workers (15) identified a pathogenicity island in strain 8ra, and determined that in addition to pepper and tomato, 8ra induces the HR on Chinese cabbage and Arabidopsis thaliana ecotype Cvi-0. However, 8ra did not induce an HR in tobacco plants $(11,14,15,20)$. We have previously shown that strains of $X$. axonopodis pv. glycines differ in their ability to induce the HR on several plant species including tobacco and that the HR can be blocked by inhibitors of eukaryotic metabolism (12).

Plant-pathogen interactions including the HR and disease are often affected by three classes of bacterial proteins that include harpins (28), avirulence proteins (17), and pectic enzymes (9). Pectate lyase (pel) isozymes cleave $\alpha$-1,4-galacturonosyl linkages in plant cell wall pectic polymers, resulting in tissue maceration and cell death due to osmotic fragility. Although Pels have been shown to play significant roles in pathogenesis of certain bacterial pathogens (7), their role in HR induction has not been demonstrated. The objectives of this study were to generate HR mutants of $X$. axonopodis pv. glycines strain KU-P-34017 and to identify associated genes and potential mechanisms that affect HR devel-

Corresponding author: T. J. Burr; E-mail address: tjb1@ cornell.edu

DOI: 10.1094/PHYTO-96-1230

(C) 2006 The American Phytopathological Society 1.4-kb DNA fragment carrying the transposon insertion contained a single open reading frame that showed high homology with PSTRU-3, a pectate lyase gene in $X$. axonopodis pv. malvacearum. Complemented KU-PM670 regained HR induction on tobacco and also pectolytic activity. Treatment of plants with inhibitors of eukaryotic metabolism blocked HR induction by wild-type strains and by complemented KU-P-M670. The presence of the pectate lyase homolog, which we designated $x a g P$, in 26 $X$. axonopodis pv. glycines strains was highly correlated with their ability to induce an HR on tobacco. To our knowledge, this is the first study indicating a role for a functional pectate lyase in induction of a plant HR.

Additional keywords: harpin.

opment on tobacco. A pel homolog designated xagP was identified and shown to be associated with induction of the HR on tobacco and pepper.

\section{MATERIALS AND METHODS}

Bacterial strains and growth condition. Bacterial strains and plasmids used in this study are shown in Table 1. X. axonopodis pv. glycines strains were grown on nutrient glucose agar (NGA) or nutrient yeast extract (NBY) agar (29) at $28^{\circ} \mathrm{C}$. Escherichia coli was grown on Luria-Bertani (LB) agar or broth at $37^{\circ} \mathrm{C}$. The optical densities of bacterial suspensions were determined with a spectrophotometer (Spectronic 20; Spectronic Instruments Inc., Rochester, NY), and the cell counts at the various optical densities were determined by dilution plating. Media were amended with ampicillin $(100 \mu \mathrm{g} / \mathrm{ml})$, kanamycin $(50 \mu \mathrm{g} / \mathrm{ml})$, and genta$\operatorname{micin}(50 \mu \mathrm{g} / \mathrm{ml})$.

HR induction. The ability of $X$. axonopodis pv. glycines to induce an HR was assayed on four species of tobacco (Nicotiana glauca, N. rustica, N. tabacum cv. Xanthi, and N. benthamiana) and on pepper (Capsicum annuum cv. Cayenne), sesame (Sesamum indicum), tomato (Lycopersicon esculentum cv. Seeda 4), and cucumber (Cucumis sativus) as previously described (12). Bacterial suspensions at cell densities of about $5.0 \times 10^{9}$ colony forming units $(\mathrm{CFU}) / \mathrm{ml}$ were infiltrated into the leaf mesophyll through a pin puncture with a 1-ml hypodermic syringe without a needle (28). Infiltrated areas were monitored for development of HR for $48 \mathrm{~h}$ postinoculation.

Mutagenesis. Transposon mutants of KU-P-34017 were made with the EZ::TN<KAN-2>Tnp Transposome System (Epicenter, Madison, WI). KU-P-34017, which causes a reliable HR on several plant species, is weakly virulent as a pathogen on soybean (12). The EZ::TN transposome is comprised of a hyperactive Tn5derived transposase and a linearized transposon that contains a selectable marker flanked at each end by modified 19-bp transpo- 
sase recognition sequences of Tn5. The transposome was introduced into cells of $X$. axonopodis pv. glycines by electroporation. Electrocompetent cells of KU-P-34017 were produced as described by White and Gonzalez (29). One microliter of EZ::TN transposome, $50 \mu \mathrm{l}$ of $X$. axonopodis pv. glycines electrocompetent cells, and $1 \mu \mathrm{l}$ of TypeOne restriction inhibitor (Epicenter) were mixed and put in a $0.25-\mathrm{cm}$ electroporation cuvette on ice. The cells were electroporated with a Bio-Rad GenePluser Xcell electroporation system (Bio-Rad, Hercules, CA) at 25,000 V/cm, $200 \mathrm{ohms}$, and $25 \mu$ farads. One milliliter of NBY broth was added to the cells and placed into a microcentrifuge tube and shaken at $28^{\circ} \mathrm{C}$ for $1 \mathrm{~h}$. Transformation mixtures were plated onto NBY agar and NBY agar supplemented with kanamycin at $50 \mu \mathrm{g} / \mathrm{ml}$. The cultures were incubated at $28^{\circ} \mathrm{C}$ for $48 \mathrm{~h}$. Selective and nonselective plating allowed for the determination of the transformation efficiency. All of the $X$. axonopodis pv. glycines mutants were initially screened for their ability to cause the HR on $N$. glauca because $N$. glauca was previously shown to be most responsive (11). Mutants that appeared HR-negative were tested for their ability to cause the HR on the other tobacco species (N. tabacum cv. Xanthi, N. rustica, and N. benthamiana) and on cucumber, pea, pepper, tomato, and sesame. One mutant of KU-PM670 was found to be HR-negative on tobacco and pepper.

Identification of transposome flanking sequences. DNA manipulations and polymerase chain reaction (PCR) were performed according to standard protocols (25) and to the supplier's directions. A 3-kb fragment from KU-P-M670 that included the transposon insertion was digested with EcoRI and cloned into pBluescript II SK(-) (Stratagene, La Jolla, CA). pBS670/1 was transformed by electroporation into E. coli DH5 $\alpha$ (Invitrogen, Carlsbad, CA). The clones were selected on LB agar amended with kanamycin and ampicillin and verified by PCR amplification of an 800-bp product using the EZ::TN-derived primers KAN-1FP and KAN-1-RP. Genomic sequences flanking the EZ::TN transposon in KU-P-M670 were identified by PCR amplification of the 3-kb fragment with primers KAN-2-FP and KAN-2-RP (Epicenter) and with pBluescript universal primers. The PCR products were cloned into pGEM-T easy vector (Promega, Madi- son, WI) and sequenced. Primer walking and PCR were employed for amplification and sequencing of the entire 3-kb fragment. Further analysis was done using BLASTP to identify possible translation products within the fragment. All primer sequences are listed in Table 2. DNA sequencing was done at the Cornell Biotechnology Center and at the Bioservice Unit, National Science and Technology Development Agency (NSTDA), Thailand. The nucleotide sequences were assembled and analyzed using programs in the Lasergene software package (DNASTAR, Inc., Madison, WI). Vecscreen and open reading frame (ORF) Finder tools in GenBank were used to identify nucleic acid sequences of the vector and ORF. Blast programs were used for homology searches (2).

Complementation. To complement KU-P-M670, the multiple cloning site vector pBBR1MSC-5 (16) was used. Primers PelF-1FP and PelF-1-RP, including restriction sites for enzymes KpnI and $S a c \mathrm{I}$, respectively, were used to amplify a $1.4-\mathrm{kb}$ product that includes the entire $x a g P$ gene from KU-P-34017. The amplified fragment and plasmid were digested with $K p n I$ and $S a c \mathrm{I}$ and the fragment was ligated into the pBBR1MCS-5(pBBRPEL) and mobilized into KU-P-M670 by electroporation. Plasmid pBBRPEL was also introduced into $X$. axonopodis pv. glycines wild-type strain CM9-015, which is virulent on soybean and HR-minus on tobacco. Selection of transformants was accomplished on NBY medium amended with kanamycin and gentamicin. They were verified by PCR and by their ability to cause an HR on tobacco.

Pectolytic activity. Because the putative gene $x a g P$ appeared to encode a pectate lyase, assays were done to measure pectolytic activity. Slices of potato tubers (Solanum tuberosum) were inoculated with cells of $X$. axonopodis pv. glycines strains that were grown $24 \mathrm{~h}$ on NGA. A toothpick was dipped in the bacterial culture and then stabbed into the surface of the potato slice. The slices were incubated on moist filter paper at $28^{\circ} \mathrm{C}$ in petri dishes and the development of soft rot was evaluated after 24 to $48 \mathrm{~h}$. The strains were also assayed for production of pectolytic enzymes using an activity stain overlay technique (23). One percent agarose plus $0.1 \%$ polygalacturonic acid that was dissolved by boiling in either $50 \mathrm{mM}$ potassium acetate $(\mathrm{pH} 4.5), 100 \mathrm{mM}$

TABLE 1. Bacterial strains and plasmids

\begin{tabular}{|c|c|c|}
\hline Strain or plasmid & Relevant characteristics ${ }^{\mathrm{a}}$ & Source or references \\
\hline Escherichia coli $\mathrm{DH} 5 \alpha$ & 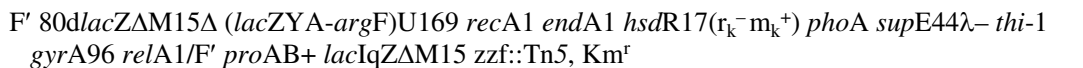 & Invitrogen \\
\hline E. coli DH5 $\alpha(\mathrm{pBBRPEL})$ & E. coli DH5 $\alpha$ carrying pBBRPEL & This study \\
\hline KU-P-34017 & Wild type, $\mathrm{HR}^{+}$ & Kaewnum et al. (12) \\
\hline CM9-015 & Wild type, $\mathrm{HR}^{-}$ & Kaewnum et al. (12) \\
\hline KU-P-M670 & HR $^{-}$mutant::Tn5-Km ${ }^{\mathrm{r}}$ of KU-P-34017 & This study \\
\hline KU-P-M670(pBBRPEL) & $\mathrm{HR}^{-}$mutant::Tn5-Km ${ }^{\mathrm{r}}$ of KU-P-34017 carrying pBBRPEL & This study \\
\hline pBluescript II SK(-) & Phagemid, pUC derivative: $l a c Z, A m p^{r}$ & Stratagene \\
\hline pGEM-T easy & PCR cloning vector, $l a c Z, \mathrm{Amp}^{\mathrm{r}}$ & Promega \\
\hline pBBR1MCS-5 & Broad host range cloning vector, $l a c Z, \mathrm{Gm}^{\mathrm{r}}$ & Kovach et al. (16) \\
\hline $\mathrm{pBS670/1}$ & 3-kb EcoRI fragment containing transposon insertion from KU-P-M670 in pBluescript II SK(-) & This study \\
\hline pBBRPEL & 1.4-kb PCR fragment with $x a g P$ in the $\mathrm{pBBR} 1 \mathrm{MCS}-5, \mathrm{Km}^{\mathrm{r}} \mathrm{Gm}^{\mathrm{r}}$ & This study \\
\hline
\end{tabular}

${ }^{\mathrm{a}} \mathrm{Km}^{\mathrm{r}}$, kanamycin resistance; $\mathrm{Amp}^{\mathrm{r}}$, ampicillin resistance; and $\mathrm{Gm}^{\mathrm{r}}$, gentamicin resistance.

TABLE 2. Polymerase chain reaction primers

\begin{tabular}{lll}
\hline Primer & \multicolumn{1}{c}{ Sequence } & \multicolumn{1}{c}{ Description } \\
\hline KAN-1-FP & 5' AAG CC GAT GCG CCA GAG TT 3' & Amplification of kanamycin gene (600 bp) \\
KAN-1-RP & 5' CGC CGT CCC GTC AAG TCA G 3' & \\
PEL-1-FP & 5' CGA ACC CAT TCG AGG GAG ACA 3' & Amplification of 600 bp of $x a g P$ \\
PEL-1-RP & 5' TGA CGG CAG TGC CGG CAA CT 3' \\
PelF-1-FP & 5' ATG CGG TAC CAC TGT CTC CAC GTG TC 3' & Amplification of $x a g P(1.4 \mathrm{~kb})$ \\
PelR-1-RP & 5' TCG AGA GCT CTC TAA CGC CGC CAA AA 3' & \\
KAN-2-FP & 5' ACC TAC AAC AAA GCT CTC ATC AAC C3' & For sequencing \\
KAN-2-RP & 5' GCA ATG TAA CAT CAG AGA TTT TGA G 3' & \\
\hline
\end{tabular}


potassium phosphate $(\mathrm{pH} 6.5)$, or $50 \mathrm{mM}$ Tris hydrochloride ( $\mathrm{pH} 8.5)$ were poured into petri dishes. Strains were spotted on the surfaces of the gels with a sterile toothpick, incubated overnight, and then washed from the gels with a stream of water. The surface of the gels were flooded with $0.05 \%$ (wt/vol) ruthenium red for $20 \mathrm{~min}$ and rinsed in water. Pectolytic activity was observed as clear zones at points where the bacteria were spotted.

Effect of plant metabolic inhibitors. The effect that inhibitors of eukaryotic metabolism have on HR induction by KU-P-34017 was previously measured (12). Inhibitor assays were repeated with KU-P-34017 and with complemented KU-P-M670. Bacteria were suspended in aqueous solutions of lanthanum chloride $(1.0 \times$ $\left.10^{-3} \mathrm{M}\right)$ or cobalt chloride $\left(5.0 \times 10^{-4} \mathrm{M}\right)$, both inhibitors of calcium channels. Tobacco species $N$. tabacum cv. Xanthi and $N$. glauca leaves were infiltrated with bacterial suspensions containing about $5.0 \times 10^{9} \mathrm{CFU} / \mathrm{ml}$ suspended in the inhibitors, in sterile distilled water or with inhibitor solutions alone. It was previously determined that the inhibitors do not affect growth of the bacterium (12). Development of the HR was recorded $48 \mathrm{~h}$ after infiltration.

Nucleotide sequence accession number. The complete DNA sequence of $x a g P$ was deposited as GenBank accession no. AY725200.

\section{RESULTS}

The EZ::TN transposome system was highly efficient for generating mutations in KU-P-34017. After optimization of the electroporation protocol, a transformation frequency of approximately $6.57 \times 10^{6}$ transformants per $\mu \mathrm{g}$ of DNA was obtained. More than 4,000 individual mutants were tested for HR on N. glauca. Infiltrated areas initially appeared water-soaked and eventually collapsed and became dark and necrotic within $48 \mathrm{~h}$ postinoculation. One mutant, KU-P-M670, lost the ability to cause the HR on all tobacco species and on pepper but still induced the HR on tomato, cucumber, and pea.

EZ::TN transposome flanking sequences. In mutant KU-PM670, the EZ::TN transposome was inserted into an ORF that has a high level of identity (97\% at amino acid level) to a pectate lyase encoding gene (PSTRU-3, accession no. AAC41522) found in $X$. axonopodis pv. malvacearum (18). The HR-associated gene, designated $x a g P$, is predicted to be $1,134 \mathrm{bp}$ in length with an overall $\mathrm{G}+\mathrm{C}$ content of $61.29 \%$, which is lower than the average of $65 \%$ for Xanthomonas spp. (8). In addition to PSTRU-3, the deduced amino acid sequence of $x a g P$ has $93 \%$ identity to Pels in $X$. campestris pv. campestris strain 8004 (YP244653) and ATCC 33913 (AAM39960), as well as genes in X. campestris pv. vesicatoria strain 85-10 (91\%, CAJ25418), X. axonopodis pv. citri strain 306 (90\%, AAM38405), X. campestris pv. campestris strain 33913 (87\%, AAM39961), X. oryzae pv. oryzae KACC10331 (86\%, AAW74075), and Pseudomonas viridiflava (80\%, BAA08077). The deduced amino acid sequence of $x a g P$ is shown in Figure 1. Gene $x a g P$ is predicted to encode a pectate lyase consisting of 378 amino acids having a molecular mass of $41.5 \mathrm{kDa}$. The predicted ribosomal binding site, -GGAG-, is located 9 nucleotides upstream from the start codon. A predicted signal peptide, M K P K F S T A A A A S L F V G S L L V V G V A C A, initiating at the protein start $\mathrm{M}$, was identified using the SignalP Server website (available online from the Center for Biological Sequence Analysis [CBS], BioCentrum-DTU, Technical University of Denmark).

HR and pectolytic activity. Complementation of KU-P-M670 resulted in regained ability to induce an HR on all of the tobacco species as well as on pepper (Fig. 2). The infiltrated leaf area showed the first signs of tissue collapse within $12 \mathrm{~h}$ after inoculation and the zone became necrotic within 48 h. E. coli DH5 $\alpha$ (pBBRPEL) did not induce the HR (Fig. 1). KU-P-34017 caused a visible soft rot on potato tubers $48 \mathrm{~h}$ after inoculation
(Fig. 3). In contrast, KU-P-M670 showed a greatly reduced level of soft rot. We determined by the pectolytic activity stain gel technique that KU-P-34017 expressed activity as broad clear zones at $\mathrm{pH}$ values of 6.5 and 8.5 , but not at 4.5 (Fig. 3). In contrast, KU-P-M670 did not show pectolytic activity at $\mathrm{pH} 6.5$ and induced smaller clear zones than the wild-type strain at $\mathrm{pH}$ 8.5. Complemented KU-P-M670 regained soft rot activity on potato (Fig. 3) and also showed pectolytic activity in the agarose gel assay. Interestingly, complemented KU-P-M670 induced clear zones that were larger than those of the wild-type strain. As indicated previously, KU-P-34017 is a weak pathogen causing pustule disease on soybean, making it impossible to determine whether the $x a g P$ mutation led to a reduction in virulence. It did not appear to enhance virulence. Considering our previous results on relative strain virulence (12), together with the results in Table 3, we predict that $x a g P$ expression is not correlated with the level of virulence.

Twenty-six $X$. axonopodis pv. glycines strains that were previously tested for HR induction (12) were examined for presence of a 1.4-kb PCR product that contains xagP using PCR primers PelF-1-FP and PelR-1-RP. They were also examined for pectolytic activity on potato with the activity stain method. The strains could be placed in three groups corresponding to HR induction, the presence of $x a g P$, and pectolytic activity. A high correlation between presence of $x a g P$, pectolytic activity, and induction of HR on tobacco was observed (Table 3). Twelve strains that did not induce an HR in tobacco lacked $x a g P$ and were negative for pectolytic activity. We determined that 3 of the 26 strains that only induce the HR on $N$. benthamiana did not show pectolytic activity or the presence of the $x a g P$ PCR product.

Effect of plant metabolic inhibitors. Treatment of plants with the metabolic inhibitors cobalt chloride and lanthanum chloride completely blocked HR induction by KU-P-34017 on tobacco. The inhibitors also affected HR induction by complemented KUP-M670; however, the inhibition was not always complete and depended on the inhibitor and plant as shown in Table 4. Inhibitors infiltrated into leaves alone had no visible toxic effects on the plants and did not affect growth of KU-P-34017 in vitro.

\section{DISCUSSION}

Microbial-induced plant defense responses are frequently accompanied by expression of the HR, i.e., rapid death of affected plant cells and induction of defense responses. The HR resembles a form of programmed cell death that involves the delivery of specific effector proteins via a type III secretion system $(1,3)$. The interaction of the effectors with plant receptors can lead to disease (in a compatible host) or induction of the HR (in nonhost). The HR is associated with a set of hrp (HR and pathogenicity) and $h r c$ (HR and conserved) genes. Such genes are often located in bacterial genomes in clusters called pathogenicity islands. Kim et al. (15) determined that a 29-kb island exists in X. axonopodis pv. glycines strain 8ra and that its structure is highly similar to those in other Xanthomonas spp. By mutational analysis, they determined that several genes on the island are essential for HR induction. Two of the genes, $h r p G$ and $h r p X$, were found to be involved in the regulation of several of the hrp, hrc, and hpa (HR-associated) genes. Infiltration of leaves with 8ra cells resulted in an HR on pepper and tomato plants but not on tobacco. However, when 8ra was transformed with a multicopy plasmid expressing $h r p G$ and $h r p X$, it gained the ability to induce the HR on tobacco. It was also discovered that $8 \mathrm{ra}$ encodes a harpin, $\mathrm{HpaG}$, and that the purified protein is able to induce the HR on pepper and tobacco but not on tomato (14). We found that the HR is induced in tobacco by several strains of $X$. axonopodis pv. glycines as well as on other nonhost plants including tomato, pepper, sesame, and cucumber (12). From a collection of strains isolated from soybean in Thailand, however, the ability to induce the HR on different 
plant species varied considerably. Collectively, these results indicate the likelihood that multiple mechanisms and elicitors of the HR are likely to exist in $X$. axonopodis pv. glycines and that the HR on tomato is induced in an $h r p$-independent manner. It is also suggested that expression levels of specific genes may determine whether the HR develops on specific plant species.

Two major categories of bacterial proteins are known to induce the HR. Avirulence (Avr) proteins interact specifically with plant receptors in a gene-for-gene manner and are delivered intracellularly to plant cells via the type III secretion system. In contrast, HR induction by harpins is not cultivar specific; they are also produced by several bacterial species and the purified proteins are able to induce the HR when delivered to the plant leaf apoplast. Bacteria may produce one or more harpins and Avr proteins as well as other effector proteins that play roles in HR induction. We also suggest that harpins do not induce the HR on protoplast cultures and appear to require interaction with plant cell walls for HR induction. Harpins are glycine-rich and generally share little sequence homology. In addition to the well-studied harpins HrpN from Erwinia amylovora and HrpZ from Pseudomonas syringae pv. tomato, HrpW harpins from these bacteria have also been identified. HrpW harpins from Erwinia amylovora and $P$. syringae pv. tomato are composed of two domains: the N-terminal harpin domain and the C-terminal pectate lyase domain $(6,13)$. A $P$. syringae pv. tomato hrpZ and hrpW double mutant was significantly reduced in HR elicitation activity in tobacco (6). Like HrpN, HrpW of Erwinia amylovora can induce the HR following infiltration of the purified protein into tobacco and by overexpressing $h r p W$ in an $h r p N$ mutant (13). Although HrpW does not express pectolytic activity, it has been shown that the Pel domain is able to bind pectin and therefore is likely to be involved in targeting HrpW to the plant cell wall (6). It was proposed that this interaction may be essential for HR induction on certain plant species and that the Pel domain may function in "loosening" the plant cell wall, thereby facilitating induction of the HR (13). In the present study, we show that the ability of strain KU-P-34017

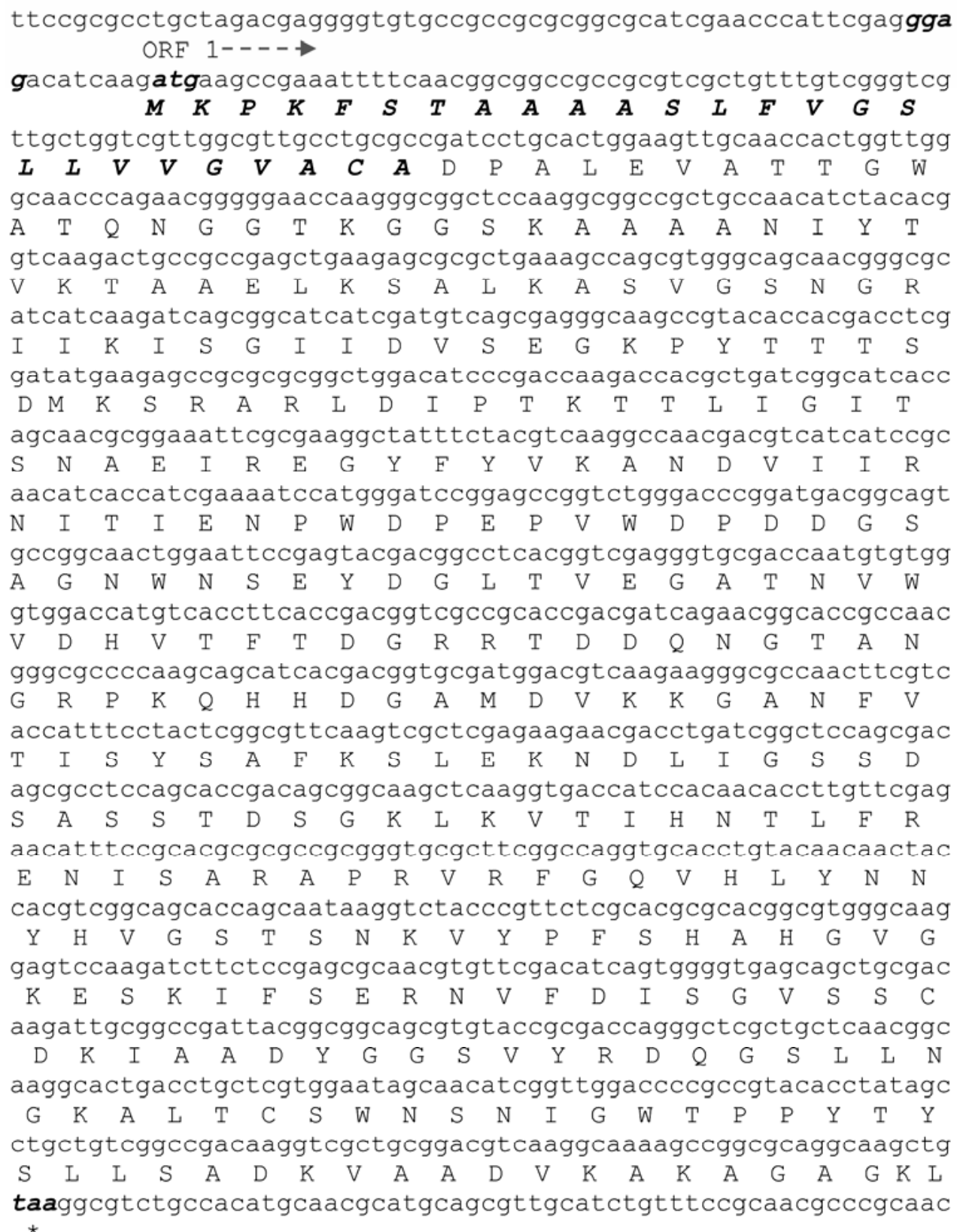

60

120

Fig. 1. The 1,134-bp nucleotide sequence of $x a g P$ from Xanthomonas axonopodis pv. glycines. The deduced amino acid is given in the single letter code below codons. The ribosome binding site, atg start codon and taa stop codon are in bold and italics. A predicted signal peptide consisting of 26 amino acids is shown in bold italics beginning with the start $\mathrm{M}$ of the deduced protein. 


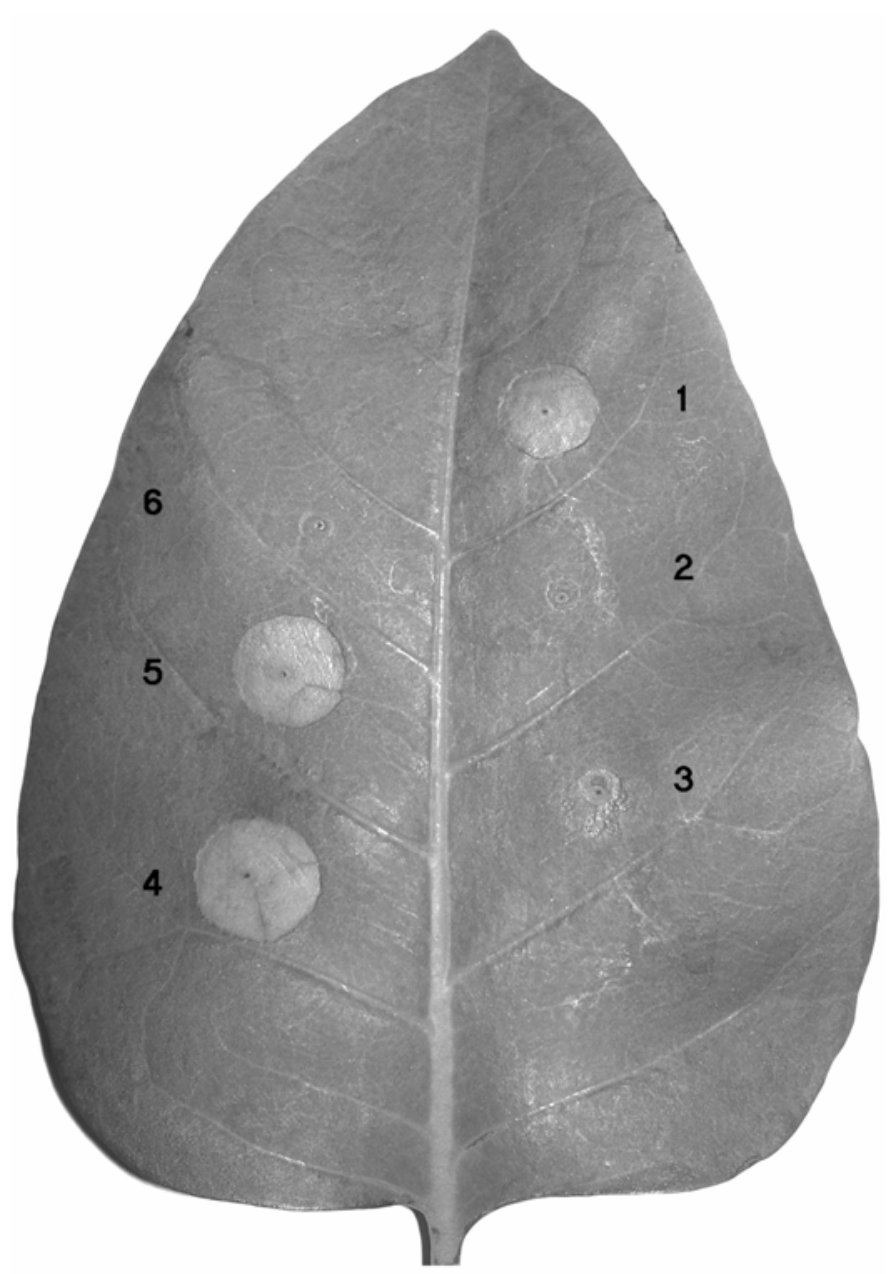

Fig. 2. Comparison of hypersensitive response (HR) induction on tobacco by wild-type strain KU-P-34017 (1), HR-minus mutant KU-P-M670 (2), HRminus wild-type strain CM9-015 (3), KU-P-M670(pBBRPEL) (4), CM9015(pBBRPEL) (5), and Escherichia coli DH5 $\alpha$ (pBBRPEL) (6). Bacteria were infiltrated into tobacco leaves (Nicotiana glauca) as described in text.

to induce the HR on tobacco is associated with the presence of a putative gene, $x a g P$, that confers the expression of pectolytic activity. Induction of the tobacco HR was found to be strongly correlated within $X$. axonopodis pv. glycines strains with the presence of $x a g P$, a putative pectate lyase. Certain wild-type strains such as CM9-015 do not carry $x a g P$ and do not induce the tobacco HR unless transformed with pBBRPEL. Interestingly, it was previously reported that $X$. axonopodis pv. glycines 8ra (also negative for HR on tobacco) does not express pectolytic activity $(11,20)$ and does not cause an HR on tobacco, but does so on pepper. In contrast, mutant KU-P-M670 (with insertion in $x a g P$ ) lost the ability to induce an HR on tobacco and pepper, and the HR was restored following complementation with $x a g P$. Again, such results demonstrate the variability between $X$. axonopodis pv. glycines strains and how they induce the HR on different plant species. These results also suggest that the putative pectate lyase encoded by $x a g P$ may function as an effector but is not essential for HR induction on pepper or tobacco. Pectate lyases degrade polygalacturonates and other pectic components in plant cell walls and are principal pathogenicity factors associated with tissue maceration caused by most strains of soft rot as well as other bacterial species $(4,7,9,18,19)$. The specific role of $x a g P$ is unknown; however, it may have similar functions as HrpW, and its direct effect on the plant cell wall may result in increased sensitivity of certain plant species to HR induction.

We observed that $E$. coli carrying pBBRPEL did not cause potato tissue maceration, show pectolytic activity at $\mathrm{pH} 6.5$, or
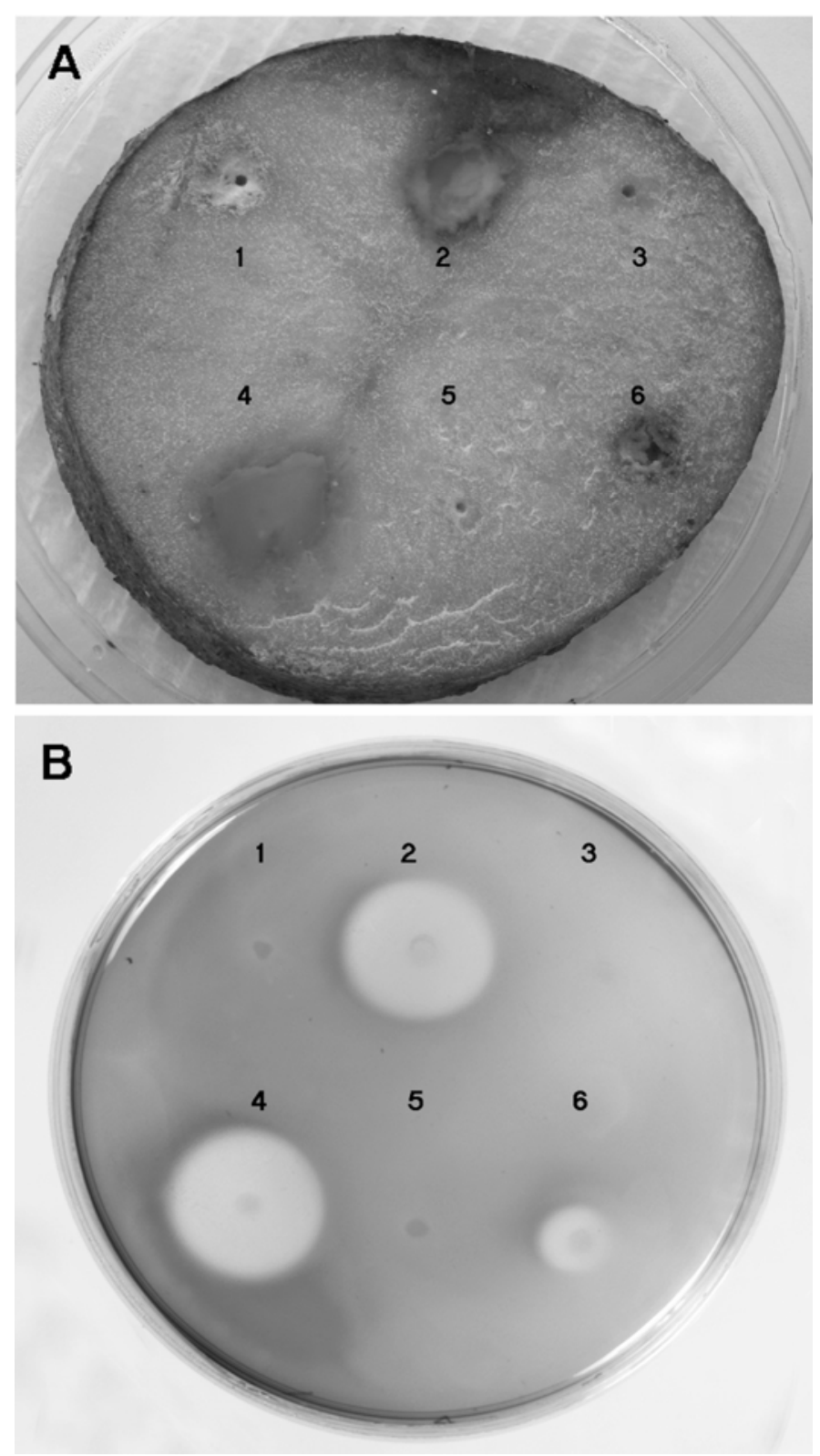

Fig. 3. A, Soft rot development on potato and B, expression of pectolytic activity at pH 6.5 as described in text: 1, Xanthomonas axonopodis pv. glycines mutant KU-P-M670; 2, KU-P-34017; 3, CM9-015; 4, KU-P-M670(pBBRPEL); 5, Escherichia coli DH5 $\alpha$ (pBBRPEL); and 6, CM9-015(pBBRPEL).

induce the HR. It is likely that E. coli does not secrete the putative $x a g P$-encoded pectate lyase. Salmond (24) reported that in Erwinia chrysanthemi, Pels are secreted in the extracellular medium by a two-step secretion system that involves transfer through the cytoplasmic membrane and cleavage of the peptide sequence which is dependent on the sec system. Subsequently, transfer of the protein through the outer membrane is dependent on the specific out system. In E. coli, the lyase would logically be retained in the periplasm because of the lack of the out secretion machinery.

We have previously reported that the inhibitors of $\mathrm{Ca}^{2+}$ channels, cobalt chloride and lanthanum chloride, as well as other inhibitors of eukaryotic metabolism inhibit HR induction by $X$. axonopodis pv. glycines strain KU-P-34017 (12). It is known that $\mathrm{Ca}^{2+}$ plays an important role as a messenger in a variety of biochemical processes in plants including defense reactions (26). Tardy et al. (27) reported that the activity of the major Erwinia chrysanthemi Pels shows an absolute requirement for $\mathrm{Ca}^{2+}$ ions with the optimal concentration, $0.1 \mathrm{mM}$, and with potential lyase inhibition at high 
TABLE 3. Relationship between hypersensitive response (HR) induction, pectolytic activity, and the presence of xagP in strains of Xanthomonas axonopodis pv. glycines from Thailand

\begin{tabular}{|c|c|c|c|c|c|c|c|c|c|c|}
\hline \multirow[b]{2}{*}{ Group } & \multirow{2}{*}{$\begin{array}{l}\text { No. of } \\
\text { strains }\end{array}$} & \multicolumn{4}{|c|}{ HR on Nicotiana species } & \multicolumn{5}{|c|}{ Pectolytic activity ${ }^{\mathrm{a}}$} \\
\hline & & glauca & benthamiana & rustica & tabacum Xanthi & 4.5 & 6.5 & 8.5 & Potato rot & $x a g P$ PCR product \\
\hline 1 & 12 & - & - & - & - & - & - & - & - & - \\
\hline 2 & 11 & + & + & + & + & - & + & + & + & + \\
\hline
\end{tabular}

a The bacterial suspension of 20 strains of X. axonopodis pv. glycines were infiltrated into N. glauca, N. benthamiana, N. rustica, and N. tabacum cv. Xanthi, which monitored for development of HR for $48 \mathrm{~h}$ postinoculation. Slices of potato tubers (Solanum tuberosum) and the activity stain overlay technique were assayed for production of pectolytic enzymes as described in text. Primers PelF-1-FP and PelR-1-RP confirmed the presence of xagP gene in X. axonopodis pv. glycines strains.

TABLE 4. Effect of plant metabolic inhibitors on induction of tobacco hypersensitive response (HR) by KU-P-34017 and complemented KU-P-M670

\begin{tabular}{|c|c|c|c|c|c|}
\hline \multirow[b]{2}{*}{ Inhibitor } & \multirow[b]{2}{*}{ Probable target } & \multirow[b]{2}{*}{ Concentration } & \multirow[b]{2}{*}{ Strain } & \multicolumn{2}{|c|}{ Percent inhibition of HR on Nicotiana species } \\
\hline & & & & N. tabacum cv. Xanthi & N. glauca \\
\hline Cobalt chloride & $\mathrm{Ca}^{2+}$ channel & $5.0 \times 10^{-4} \mathrm{M}$ & $\begin{array}{l}\text { KU-P-34017 } \\
\text { KU-P-M670(pBBRPEL) }\end{array}$ & $\begin{array}{r}100 \\
60\end{array}$ & $\begin{array}{l}100 \\
100\end{array}$ \\
\hline
\end{tabular}

${ }^{a}$ Bacterial cells were suspended in each of the inhibitors at cell densities of about $5.0 \times 10^{9} \mathrm{CFU} / \mathrm{ml}$ and then infiltrated into the tobacco leaf panels as described in text. Infiltrated areas were monitored for development of tissue collapse and necrosis for $48 \mathrm{~h}$ postinoculation.

$\mathrm{Ca}^{2+}$ concentration. In this paper, we report that inhibitors of calcium channels completely inhibit the HR of KU-P-34017. HR induction by KU-P-M670 (pBBRPEL) and CM9-015(pBBRPEL) was also inhibited, but to a lesser degree, on some plants. One explanation for this result may be that over-production of lyase, as suggested by the size of clear zones on the activity stain plates, enhances cell sensitivity to the HR elicitors. It was reported by Blume et al. (5) that the degree of the elicitor induction was biphasic and dependent on the extracellular $\mathrm{Ca}^{2+}$ and that induction could be inhibited in the presence of $\mathrm{La}^{+}$, by inhibitors of $\mathrm{Ca}^{2+}$ channels. However, none of the tested inhibitors of $\mathrm{Ca}^{2+}$ anion channels completely cancelled the depolarization (30). In addition, the optimal $\mathrm{Ca}^{2+}$ concentration varied with the methylation of substrate and with the $\mathrm{pH}$ of the medium. These results reflect the complex effects of $\mathrm{Ca}^{2+}$ in the reaction (27) and provide further explanation as to why the inhibitors did not completely block the HR of the complemented mutant. The fact that inhibitors block the HR of wild type and complemented strains indicates that the putative pectate lyase encoded by $x a g P$ does not function alone in causing the tobacco HR.

$X$. axonopodis pv. glycines appears to be a highly heterogeneous bacterial species that varies greatly with regard to its pathogenicity and HR on plant species. Further research is warranted to identify specific strain differences and to determine how effectors of pathogenicity and the HR interact with the plants. To our knowledge, this is the first report to demonstrate that a functional pectate lyase plays a role in HR induction on certain plants. The specific role of the enzyme and how it affects sensitivity of plant cells is being investigated.

\section{ACKNOWLEDGMENTS}

This work was supported by Royal Golden Jubilee-Ph.D. scholarship from the Thailand Research Fund. We thank P. Chiemsombat and C. Leksomboon for kind recommendations; and J. Burr, C. Reid, G. Hao, and Y. Li for providing technical assistance at New York State Agricultural Experiment Station (NYSAES), Cornell University (Geneva, NY).

\section{LITERATURE CITED}

1. Alfano, J. R., and Collmer, A. 2004. Type III secretion system effector proteins: Double agents in bacterial disease and plant defense. Annu. Rev. Phytopathol. 42:385-414.

2. Altschul, S. F., Madden, T. L., Schaffer, A. A., Zang, J., Zhang, Z., Miller, W., and Lipman, D. L. 1997. Gapped BLAST and PSI-BLAST: A new generation of protein databases search programs. Nucleic Acids Res. 25:3389-3402.

3. Barras, F., van Gijisegem, F., and Chatterjee, A. K. 1994. Extracellular enzymes and pathogenesis of soft rot Erwinia. Annu. Rev. Phytopathol. 32:201-234.

4. Beaulieu, C., Minsavage, G. V., Canteros, B. I., and Stall, R. E. 1991. Biochemical and genetic analysis of a pectate lyase gene from Xanthomonas campestris pv. vesicatoria. Mol. Plant-Microbe Interact. 4:446-451.

5. Blume, B., Nurnberger, T., Nass, N., and Scheel, D. 2000. Receptormediated increase in cytoplasmic free calcium required for activation of pathogen defense in parsley. Plant Cell 12:1425-1440.

6. Charkowski, A. O., Preston, G., Yuan, J., He, S. Y., and Collmer, A. 1998. The Pseudomonas syringae pv. tomato HrpW protein has domains similar to harpins and pectate lyases and can elicit the plant hypersensitive response and bind to pectate. J. Bacteriol. 180:5211-5217.

7. Collmer, A., and Keen, N. T. 1986. The role of pectic enzymes in plant pathogenesis. Annu. Rev. Phytopathol. 24:383-409.

8. da Silva, A. C., Ferro, J. A., Reinach, F. C., Farah, C. S., Furlan, L. R., Quaggio, R. B., Monteiro-Vitorello, C. B., Van Sluys, M. A., Almeida, N. F., Alves, L. M., do Amaral, A. M., Bertolini, M. C., Camargo, L. E., Camarotte, G., Cannavan, F., Cardozo, J., Chambergo, F., Ciapina, L. P., Cicarelli, R. M., Coutinho, L. L., Cursino-Santos, J. R., El-Dorry, H., Faria, J. B., Ferreira, A. J., Ferreira, R. C., Ferro, M. I., Formighieri, E. F., Franco, M. C., Greggio, C. C., Gruber, A., Katsuyama, A. M., Kishi, L. T., Leite, R. P., Lemos, E. G., Lemos, M. V., Locali, E. C., Machado, M. A., Madeira, A. M., Martinez-Rossi, N. M., Martins, E. C., Meidanis, J., Menck, C. F., Miyaki, C. Y., Moon, D. H., Moreira, L. M., Novo, M. T., Okura, V. K., Oliveira, M. C., Oliveira, V. R., Pereira, H. A., Rossi, A., Sena, J. A., Silva, C., de Souza, R. F., Spinola, L. A., Takita, M. A., Tamura, R. E., Teixeira, E. C., Tezza, R. I., Trindade dos Santos, M., Truffi, D., Tsai, S. M., White, F. F., Setubal, J. C., and Kitajima, J. P. 2002. Comparison of the genomes of two Xanthomonas pathogens with differing host specificities. Nature 417:459-463.

9. Gomathi, S., and Gnanamanickam, S. S. 2004. Polygalacturonase-inhibiting protein in plant defence. Curr. Sci. 87:1211-1217.

10. Goodman, R. N., and Novacky, A. J. 1994. The Hypersensitive Reaction in Pathogens: A Resistance Phenomena. The American Phytopathological Society, St. Paul, MN.

11. Hwang, I., Lim, S. M., and Shaw, P. D. 1992. Cloning and Characterization of pathogenicity genes from Xanthomonas campestris pv. glycines. J. Bacteriol. 174:1923-1931.

12. Kaewnum, S., Prathuangwong, P., and Burr, T. J. 2005. Aggressiveness of Xanthomonas axonopodis pv. glycines isolates to soybean and hypersensitivity responses by other plants. Plant Pathol. 54:409-415.

13. Kim, J. F., and Beer, S. V. 1998. HrpW of Erwinia amylovora, a new harpin that contains a domain homologous to pectate lyases of a distinct class. J. Bacteriol. 180:5203-5210.

14. Kim, J. G., Joen, E., Oh, J., Moon, J. S., and Hwang, I. 2004. Mutational analysis of Xanthomonas Harpin HapG identifies a key functional region that elicits the hypersensitive response in nonhost plants. J. Bacteriol. 186:6239-6247. 
15. Kim, J. G., Park, B. K., Yoo, C. H., Jeon, E., Oh, J., and Hwang, I. 2003. Characterization of the Xanthomonas axonopodis pv. glycines Hrp pathogenicity island. J. Bacteriol. 185:3155-3166.

16. Kovach, E. M., Elzer, P. H., Hill, D. S., Robertson, G. T., Farris, M. A., Roop, R. M., II, and Peterson, K. M. 1995. Four new derivatives of the broad-host-range cloning vector pBBR1MSC, carrying different antibiotic-resistance cassettes. Gene 166:175-176.

17. Leach, J., and White, F. F. 1996. Bacterial avirulence gene. Annu. Rev. Phytopathol. 34:153-179.

18. Liao, C.-H., Sasaki, K., Nagahashi, G., and Hicks, K. B. 1992. Cloning and characterization of pectate lyase gene from the soft-rotting bacterium Pseudomonas viridiflava. Mol. Plant-Microbe Interact. 5:301-308.

19. Liao, C.-H., Gaffney, T. D., Bradley, S. P., and Wong, L.-J. C. 1996. Cloning of pectate lyase gene from Xanthomonas campestris pv. malvacearum and comparison of its sequence relationship with pel gene of soft-rot Erwinia and Pseudomonas. Mol. Plant-Microbe Interact. 9:14-21.

20. Oh, C., Heu, S., Yoo, J. Y., and Cho, Y. 1999. An hrcU-homologous gene mutant of Xanthomonas campestris pv. glycines 8ra that lost pathogenicity on the host plant but was able to elicit the hypersensitive response on nonhosts. Mol. Plant-Microbe Interact. 12:633-639.

21. Prathuangwong, S. 1983. Effects of different soybean plant ages on susceptibility of Xanthomonas campestris pv. glycines. J. Thai Phytopathol. Soc. 3:148-153.

22. Prathuangwong, S., and Amnuaykit, K.1987. Studies on tolerance and rate reducing bacterial pustule of soybean cultivars/lines. Kasetsart J. (Nat.
Sci.) 21:408-420.

23. Reid, J. L., and Collmer, A. 1985. An activity stain for the rapid characterization of pectic enzymes in isoelectric focusing and sodium dodecyl sulfate-polyacrylamide gels. Appl. Environ. Microbiol. 50:615-622.

24. Salmond, G. P. 1994. Secretion extracellular virulence factors by plant pathogenic bacteria. Annu. Rev. Phytopathol. 32:181-200.

25. Sambrook, J., Fritsch, E. F., and Maniatis, T. 1989. Molecular Cloning: A Laboratory Manual. 2nd ed. Cold Spring Harbor Laboratory, Cold Spring Harbor, NY.

26. Scheel, D. 1998. Resistance response physiology and signal transduction. Curr. Opin. Plant Biol. 1:305-310.

27. Tardy, F., Nesser, W., Robert-Baudouy, J., and Pattat, N. H. C. 1997. Comparative analysis of the five major Erwinia chrysanthemi pectate lyase: Enzyme characteristics and potential inhibitors. J. Bacteriol. 179:2503-2511.

28. Wei, Z., Laby, R. J., Zumoff, C. H., Bauer, D. W., He, S. Y., Collmer, A., and Beer, S. V. 1992. Harpin, elicitor of the hypersensitive response produced by the plant pathogen Erwinia amylovora. Science 257:85-88.

29. White, T. J., and Gonzalez, C. F. 1995. Electroporation of Xanthomonas. Pages 135-141 in: Methods in Molecular Biology, Vol. 47. J. A. Nickoloff, ed. Humana Press Inc., Totowa, NY.

30. Zimmermann, S., Nurnberger, T., Frachisse, J.-M., Wirtz, W., Guern, J., Hedrich, R., and Scheel, D. 1997. Receptor-mediated activation of a plant $\mathrm{Ca}^{2+}$-permeable ion channel involved in pathogen defense. Proc. Natl. Acad. Sci. USA 94:2751-2755. 